\title{
UPODMIOTOWIENIE - ANALIZA KONCEPCJI I JEJ ZASTOSOWANIE W PRAKTYCE PIELĘGNIARSKIEJ
}

\section{EMPOWERMENT - ANALYSIS OF THE CONCEPT AND ITS APPLICATION IN NURSING}

\author{
Agnieszka Orłowska, Mariola Łaguna \\ Instytut Psychologii, Wydział Nauk Społecznych, Katolicki Uniwersytet Lubelski Jana Pawła II
}

DOI: https://doi.org/10.20883/pielpol.2018.14

\begin{abstract}
STRESZCZENIE
Pielęgniarki stanowią grupę zawodową, bez której system opieki zdrowotnej nie jest w stanie sprawnie funkcjonować. W związku z tym ważne jest, aby kierownictwo szpitala zapewniło pielęgniarkom takie warunki pracy, które pozwolą im wykonywać swoją pracę z maksymalną dokładnością i satysfakcją. W artykule prezentujemy koncepcję upodmiotowienia, które jest określane jako wielowymiarowy proces przekazywania prawa do podejmowania decyzji w ręce pracowników, wzmacniania ich samodzielności i autonomii oraz entuzjazmu i zaangażowania. Koncepcja ta może zostać wykorzystana w organizacji pracy zawodowej pielęgniarek. Prezentujemy model teoretyczny opracowany przez Laschinger i wsp., który obrazuje wzajemne relacje zachodzące pomiędzy cechami szpitala jako organizacji, cechami pielęgniarek oraz cechami pacjenta, które powstają dzięki stosowaniu strategii upodmiotowienia. Omawiamy także implikacje tego modelu dla funkcjonowania instytucji opieki zdrowotnej oraz dla funkcjonowania pacjentów. Wzajemna współpraca pomiędzy przełożonymi, pielęgniarkami i ich pacjentami może przynosić korzyści zarówno dla szpitala jako organizacji, jak i dla samych pielęgniarek i ich pacjentów.
\end{abstract}

SŁOWA KLUCZOWE: upodmiotowienie psychologiczne, upodmiotowienie strukturalne, upodmiotowienie pacjentów, pielęgniarki, zarządzanie w opiece zdrowotnej.

\section{Wprowadzenie}

System opieki zdrowotnej jest jednym z fundamentów współczesnego państwa [1, 2]. Rosnące potrzeby zdrowotne starzejących się społeczeństw i związana $z$ tymi potrzebami presja na wzrost wydatków na opiekę zdrowotną to podstawowe wyzwania stojące dzisiaj przed rządami wielu państw, a skuteczne wykorzystanie zasobów sektora zdrowia może powstrzymać nadmierny wzrost kosztów, przy jednocześnie większych korzyściach zdrowotnych [3]. Najważniejszym czynnikiem decydującym o jakości i efektywności systemu opieki zdrowotnej są zasoby ludzkie: zdrowie i życie pacjentów, a także jakość świadczonych usług medycznych, zależna od kompetencji personelu i jakości zarządzania [4]. W literaturze od dawna wskazuje się, że aby popra-

\begin{abstract}
Nursing as a profession is indispensable to the smooth running of the health care system. Hence, nurses should be provided with conditions which allow them to do their job with maximum precision and satisfaction. The article presents the concept of empowerment which is defined as a multidimensional process of giving the employees opportunities for decision-making, encouraging autonomy, enthusiasm and engagement. The theory of empowerment may be used for managing the work of nurses. We present the theoretical model proposed by Laschinger and colleagues which shows mutual relationships between the hospital as an organization, nurses as well as patients, which is the effect of employing empowerment in the workplace. Practical implications for the system of health care as well as for functioning of the patients are discussed. Cooperation between supervisors, nurses, and their patients can benefit the hospital as an organization, as well as nurses and their patients.
\end{abstract}

KEYWORDS: psychological empowerment, structural empowerment, patients' empowerment, nurses, health care management.

wić stan opieki zdrowotnej, potrzebne są zmiany w zarządzaniu organizacjami systemu opieki zdrowotnej [4, 5]. Zmian wymaga m.in. sposób zarządzania pracą pielęgniarek i pielęgniarzy (ponieważ zawód ten wykonują głównie kobiety, w dalszej części tekstu, dla uproszczenia, posługujemy się terminem: pielęgniarki), tak aby wykonywali swoją pracę z satysfakcją [6]. Wykonywanie tego odpowiedzialnego zawodu, związanego z opieką nad innymi ludźmi, niesie bowiem wiele sytuacji trudnych, wymagań i obciążeń psychofizycznych [7, 8]. Zapewnienie odpowiednich warunków pracy stwarza szanse na efektywną opiekę nad pacjentami. Właściwy system zarządzania organizacją może przyczyniać się do redukcji stresu związanego z pracą, zwiększać przywiązanie pracownika do organizacji i poziom odczuwa- 
nego zadowolenia z pracy, przez co korzyści czerpią nie tylko pracownicy ochrony zdrowia, ale także ich pacjenci $[7,8]$.

Celem artykułu jest prezentacja koncepcji upodmiotowienia (ang. empowerment) oraz jej zastosowania w zarządzaniu personelem medycznym. Została ona zaczerpnięta z obszaru badań nad organizacjami i z powodzeniem zaadoptowana do zarządzania w placówkach opieki zdrowotnej, przede wszystkim w pracy pielęgniarek.

\section{Ogólna charakterystyka upodmiotowienia}

Zanim przejdziemy do analizy strategii zarządzania określanej angielskim terminem: empowerment, proponujemy najpierw przyjrzeć się jego tłumaczeniom na język polski, gdyż, podobnie jak w przypadku innych pokrewnych pojęć [9], panuje tu pewne zamieszanie terminologiczne. W literaturze polskojęzycznej można odnaleźć takie określenia jak: upodmiotowienie [10, 11], upełnomocnienie [12-14], uwłasnowolnienie [15], uprawnienie [16] czy też uprawomocnienie [17]. Ponadto część badaczy posługuje się po prostu pojęciem anglojęzycznym: empowerment bez jego tłumaczenia [10, 17]. W niniejszej publikacji przyjmujemy tłumaczenie tego terminu jako: upodmiotowienie i nim posługujemy się w całym artykule. Strategia upodmiotowienia opiera się bowiem na wdrażaniu w organizacji systemowych i konsekwentnych działań z zakresu zarządzania zasobami ludzkimi, które wzmocnią podmiotowe zaangażowanie pracowników, tworząc atmosferę otwartości i zaufania [10].

Upodmiotowienie w organizacji jest konstruktem złożonym i wielowymiarowym [13]. Może swoim zasięgiem obejmować praktycznie wszystkie sfery funkcjonowania organizacji. Ujęcia upodmiotowienia obecne w literaturze przedmiotu $[10,18]$ zwracają uwagę na kilka jego istotnych charakterystyk, takich jak: uczestnictwo pracownika w podejmowaniu decyzji, wspieranie pracowników przez przełożonych, zwiększanie ich niezależności i autonomii, co prowadzi do redukcji ich bezsilności i do wzrostu motywacji [19]. Upodmiotowienie jest procesem umożliwiającym pracownikom kreatywne działanie i podjęcie własnej inicjatywy poprzez przekazanie im możliwości podejmowania decyzji, a także odpowiedniego stopnia swobody działań przy zachowaniu pełnej odpowiedzialności za ich realizację [20]. Dzięki temu pracownicy uzyskują coraz większą kontrolę nad własnym działaniem i coraz częściej chcą uczestniczyć w podejmowaniu decyzji, które ich dotyczą [21].

Zagadnieniem upodmiotowienia zajmowano się z punktu widzenia różnych perspektyw [22], zwracając uwage przede wszystkim na aspekt pracowniczy i stopień wpływu klientów wewnętrznych na funkcjonowanie organizacji [17, 23]. Nie sposób jednak pominąć kwestii zasadniczej, a wręcz fundamentalnej przy zarządzaniu organizacjami usługowymi, a więc pozycji zewnętrznego klienta, który współtworzy system i kulturę danej organizacji (w przypadku usług medycznych będą to oczywiście pacjenci) [23]. Niniejszy artykuł odnosi się do upodmiotowienia w ujęciach Kanter i Spreitzer [18, 24-26]. Pierwsza koncepcja odnosi się do płaszczyzny organizacyjnej, określanej jako upodmiotowienie strukturalne (ang. structural empowerment), druga określa płaszczyznę psychologiczną, indywidualną dla każdego pracownika, określaną jako upodmiotowienie psychologiczne (ang. psychological empowerment) [27]. W tej publikacji poszerzamy te dwa ujęcia o dodatkowy wymiar, jakim jest upodmiotowienie pacjenta [24].

Teoria upodmiotowienia strukturalnego opisana przez Kanter oraz teoria upodmiotowienia psychologicznego opisana przez Spreitzer znalazły zastosowanie w analizach pracy zawodowej pielęgniarek [18, 24-26]. Skupiając się na funkcjonowaniu tej grupy zawodowej, przedstawimy aplikację koncepcji upodmiotowienia do zarządzania organizacjami opieki medycznej, przede wszystkim w odniesieniu do pracy pielęgniarek.

\section{Zastosowania strategii upodmiotowienia w pracy pielęgniarek}

Współcześnie wskazuje się, iż tradycyjne podejście do opieki medycznej jest niewystarczające, w związku z tym proponuje się wprowadzenie w szpitalach modelu upodmiotowienia, w którym pielęgniarki współpracują z pacjentami, aby wspólnie stworzyć optymalny poziom opieki zdrowotnej [24]. Model upodmiotowienia jest użyteczny w badaniach nad środowiskiem pracy pielęgniarek [28]. Wdrożenie strategii upodmiotowienia jest szansą na stworzenie silnego i efektywnego sektora opieki zdrowotnej [29]. Upodmiotowienie to wyzwalanie władzy drzemiącej w pielęgniarkach: ich wiedzy, doświadczenia i motywacji oraz ukierunkowanie tej siły na osiągnięcie celu, jakim jest nie tylko zdrowie i życie pacjenta, ale także obustronne poczucie komfortu i bezpieczeństwa. Pielęgniarki, kierując się własną rozwagą i roztropnością, mogą przekraczać zwyczajowe wymogi wchodzące w zakres ich obowiązków po to, by w sposób możliwie doskonały zaspokajać potrzeby pacjentów [12].

Model zaproponowany przez Laschinger i wsp. [24] przedstawia wzajemne relacje zachodzące pomiędzy cechami organizacji, cechami pielęgniarek i cechami pacjenta, które powstają dzięki stosowaniu strategii upodmiotowienia (Rycina 1). Był on weryfikowany empirycznie w ramach różnych badań, które testowały poszczególne opisywane w nim zależności głównie w środowisku zawodowym pielęgniarek. Laschinger wraz ze wsp. przeprowadziła liczne badania, które pokazały ist- 
nienie dodatnich zależności między upodmiotowieniem a satysfakcją z pracy u pielęgniarek oraz ujemnych zależności pomiędzy upodmiotowieniem a stresem i wypaleniem zawodowym w pracy pielęgniarek [26, 30, 31]. Polskie badania pokazały, że upodmiotowienie strukturalne w szpitalach sprzyja godzeniu sfery zawodowej i rodzinnej przez pielęgniarki oraz niższemu poziomowi odczuwanego konfliktu między pracą a rodziną [32].

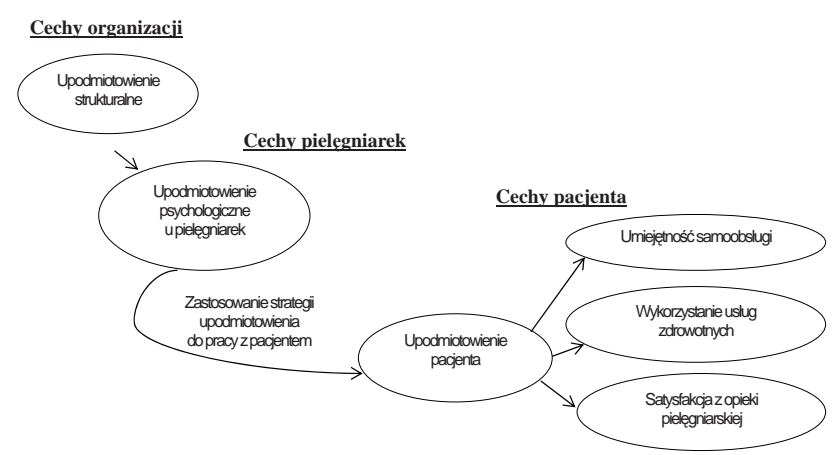

Rycina 1. Zastosowanie koncepcji upodmiotowienia w opiece zdrowotnej [24]

Figure 1. Application of the concept of empowerment in health care [24]

Z modelu opracowanego przez Laschinger i wsp. [24] wynika, iż wprowadzenie w szpitalu strategii upodmiotowienia strukturalnego, a więc wprowadzenie struktury społecznej uprawniającej do konstruktywnego wypełniania powierzonych obowiązków, wiąże się z wykształceniem się upodmiotowienia psychologicznego u pielęgniarek. Pielęgniarki, doświadczając wsparcia ze strony przełożonych, czują się kompetentne, są przekonane, że ich praca ma dużą wartość w procesie opieki nad pacjentem. Upodmiotowienie psychologiczne u pielęgniarek powstaje, gdy ich przełożeni wspierają niezależność, autonomię w podejmowaniu decyzji i wyrażają zaufanie do kompetencji swoich pracownic. Dzięki temu z kolei pielęgniarki wykorzystują nabyte zaufanie, umiejętności i doświadczenia w kontaktach z pacjentami, co prowadzi do upodmiotowienia pacjenta. Pacjenci dostrzegają, że mają większy dostęp do informacji, wsparcia i zasobów, a także mają możliwość uczenia się, jak dbać o własne zdrowie. Czują się więc psychologicznie upodmiotowieni, mają większe poczucie własnej wartości oraz odczuwają satysfakcję z opieki zdrowotnej, której doświadczyli. Upodmiotowienie strukturalne wprowadzone w szpitalu prowadzi więc ostatecznie do zapewnienia należytej opieki pacjentom, jest zatem wypełnieniem misji, jaką mają do spełnienia pracownicy służby zdrowia.

Upodmiatawiające środowisko pracy jest wsparciem dla pielęgniarek w pozytywnym postrzeganiu własnej pracy oraz źródłem ogólnego zadowolenia pacjentów z opieki zdrowotnej. Strategia upodmiotowienia zakłada, iż pacjenci zostają upoważnieni i jednocześnie zobowiązani do podjęcia aktywnego uczestnictwa w dochodzeniu do zdrowia. Nie są oni biernymi odbiorcami oddziaływań medycznych, lecz wykorzystują swój własny potencjał, dzięki czemu szybciej wracają do zdrowia. Pielęgniarki w swojej pracy współpracują z pacjentami, aby przekazać im niezbędne informacje, zasoby, a także wsparcie, którego pacjenci od nich oczekują. Istotną rolę w tym procesie odgrywają relacje pomiędzy pielęgniarkami i pacjentami oparte na zasadzie wzajemnego zaufania i szacunku. Placówki, w których zostały wdrożone programy oparte na strategii upodmiotowienia, mogą pochwalić się wysoką jakością opieki nad pacjentem oraz dążeniem do perfekcji, innowacyjności i pełnej fachowości ze strony pielęgniarek. Także pacjenci dostrzegają, że opieka zdrowotna w tych placówkach świadczona jest na bardzo wysokim poziomie [28].

\section{Trzy obszary zastosowania strategii upodmiotowienia}

Strategia upodmiotowienia może zostać zastosowana w trzech obszarach funkcjonowania instytucji służby zdrowia - może odnosić się do pracy przełożonych, pielęgniarek oraz do pacjentów. Wskażemy poniżej na specyfikę każdego z tych obszarów.

\section{Upodmiotowienie strukturalne w szpitalu}

Zakłady opieki zdrowotnej należą do organizacji, dla których zapewnienie jak najwyższej jakości świadczeń jest wartością priorytetową, bowiem dobra jakość przekłada się na zdrowie, zaufanie, bezpieczeństwo, a przede wszystkim życie pacjenta [33]. Troska o jakość usług powinna być priorytetem całego personelu zakładu, a zwłaszcza dyrekcji i całej kadry zarządzającej. Upodmiotowienie jest traktowane jako metoda zarządzania organizacją, która odnosi się także do kadry kierowniczej [34]. W ujęciu Kanter upodmiotowienie strukturalne to zdolność do mobilizacji wszelkich dostępnych możliwości, informacji, zasobów i wsparcia, aby zrealizować określony cel [24]. Kanter opisuje dwie podstawowe struktury w organizacji: strukturę możliwości (ang. structure of opportunity) i strukturę mocy (ang. structure of power). Struktura możliwości odnosi się do warunków pracy, które będą w pełni wykorzystywały umiejętności i wiedzę pracownika w sposób efektywny. Struktura możliwości zapewnia pracownikom możliwość doskonalenia zawodowego oraz awansu.

Natomiast na strukturę mocy składa się dostęp do: informacji, zasobów i wsparcia [24]. Posiadane przez pracownika informacje to nie tylko wiedza techniczna i doświadczenie zawodowe, ale także znajomość 
wartości cenionych w organizacji oraz celów i polityki kadry kierowniczej. Wiedza ta powinna być wykorzystana przez pracownika w sposób efektywny. Zasoby gwarantują pracownikowi dostęp do odpowiedniego sprzętu, materiałów, wyposażenia i środków, będących warunkiem koniecznym wykonywania powierzonych obowiązków, to także czas niezbędny pracownikowi na wykonanie obowiązków służbowych. Z kolei na wsparcie składają się przede wszystkim informacje zwrotne od przełożonych i współpracowników oraz wskazówki i informacje pomocne w rozwiązywaniu problemów.

Dostęp do powyższych struktur jest łatwiejszy, gdy w organizacji występuje upodmiotowienie formalne (ang. formal power) i upodmiotowienie nieformalne (ang. informal power) [24]. Upodmiotowienie formalne dotyczy tych aktywności pracownika, które umożliwiają mu elastyczność oraz autonomię i swobodę w podejmowaniu decyzji. Swoboda ta ma swoje źródło w prawidłowych relacjach i sojuszach pomiędzy pracownikami oraz ich przełożonymi. Natomiast upodmiotowienie nieformalne odnosi się do atmosfery, jaka panuje w organizacji. Ułatwieniu dostępu do struktur możliwości i mocy sprzyja atmosfera otwartości, wzajemnego zaufania, koleżeństwa oraz wsparcia społecznego.

Wprowadzeniu strategii upodmiotowienia w szpitalu muszą towarzyszyć zmiany w zakresie sprawowania władzy w organizacji, dostępu do informacji i wiedzy oraz przekształcenia w systemach motywacyjnych. Wymaga to nie tylko zmiany sposobu postrzegania pracy, ale przede wszystkim zmniejszenia kontroli przez przełożonych oraz woli autonomicznego działania i większego angażowania się w pracę wykonawców zadań [35]. Może to jednak nieść szereg korzyści zarówno dla organizacji, jak i dla zatrudnionych w niej pielęgniarek, co pokazują wyniki badań, prowadzonych także w Polsce [22].

\section{Upodmiotowienie psychologiczne pielęgniarek}

Omawiany model postuluje zastosowanie strategii upodmiotowienia strukturalnego w pracy pielęgniarek, dzięki czemu dochodzi do upodmiotowienia psychologicznego pielęgniarek [24]. Pielęgniarkom, poprzez fakt najczęstszego kontaktu z pacjentami i ich rodzinami, przypisuje się fundamentalne znaczenie w tworzeniu pozytywnej atmosfery hospitalizacji i w kreowaniu wizerunku placówki [33]. Wyzwania, jakie stoją w związku z tym przed każdą pielęgniarką, to zrozumienie roli i poczucie sensu oraz świadome współuczestnictwo w procesach umacniania zdrowia, leczenia, pielęgnowania i ratowania życia. Dbałość o prestiż zawodu pielęgniarki powinna być wsparta ciągłym rozwojem pielęgniarek i kształtowaniem ich świadomości co do celów działania placówki, podnoszeniem poziomu profesjonalizmu oraz formowaniem prawidłowych postaw poprzez od- powiednie zmotywowanie i zintegrowanie personelu pielęgniarskiego [33]. Zadania te mogą zostać wykonane dzięki strategii upodmiotowienia.

Upodmiotowienie psychologiczne to proces motywacyjny, w wyniku którego pracownik kształtuje osobiste przekonania o znaczeniu roli, jaką odgrywa w organizacji [18]. Proces ten może zachodzić w środowisku pracy, w którym kładzie się szczególny nacisk na motywowanie pracowników. Upodmiotowienie psychologiczne, jako rodzaj indywidualnej motywacji, obejmuje cztery wymiary: nadanie osobistego znaczenia wykonywanej pracy (ang. meaning), znajomość własnych kompetencji (ang. competence), przekonanie o możliwości dokonywania proaktywnych wyborów (ang. self-determination) i przekonanie o wartości pracy własnej (ang. impact) [27, 36, 37]. Upodmiotowiony psychologiczne pracownik wykonuje swoją pracę z ochotą, chęcią i poczuciem, że ma wpływ na to, co robi.

Nadanie osobistego znaczenia wykonywanej pracy, poczucie, że jest ona ważna, wynika z relacji pomiędzy wymaganiami stawianymi w miejscu pracy a przekonaniami, wartościami i ideałami uznawanymi przez pracowników [38]. Znajomość własnych kompetencji odnosi się do możliwości efektywnego wykonywania powierzonych obowiązków [27]. Ten wymiar upodmiotowienia psychologicznego zawiera w sobie przekonanie i wiarę pracownika w możliwość wykonywania obowiązków z należytą biegłością i profesjonalizmem. Trzeci z wymiarów, przekonanie o możliwości dokonywania proaktywnych wyborów, wiąże się z poczuciem autonomii i niezależności oraz przekonaniem pracownika, że ma on wpływ na wykonywaną prace [38]. Natomiast przekonanie o wartości własnej pracy nawiązuje do poczucia pracownika, że ma on możliwość samodzielnego wpływu i oddziaływania na miejsce pracy, przekonanie, że jego własne działania mogą mieć wpływ na istotne cele organizacji [27].

Pielęgniarki o wyższym poziomie psychologicznego upodmiotowienia przejmują większą inicjatywę w działaniu i rozwiązywaniu problemów, mają także świadomość, że pracują dla pacjenta, a nie dla przełożonych, lepiej i szybciej dostrzegają potencjał pacjentów, który starają się wykorzystać w celu wzmocnienia udziału pacjenta w powrocie do stanu równowagi zdrowotnej [35]. Zgodnie z założeniami koncepcji upodmiotowienia pielęgniarki mogą promować zdrowie pacjentów poprzez stwarzanie i zapewnianie pacjentom dostępu do warunków upodmiatawiającego środowiska szpitalnego [24].

W strategii upodmiotowienia nie ma miejsca na apodyktyczne zachowania pielęgniarek, które jako eksperci kierują procesem leczenia pacjenta i oczekują, że pacjenci będąjedynie wykonywali ich polecenia [24]. Wręcz przeciwnie, pielęgniarki powinny współpracować z pa- 
cjentami w dążeniu do optymalizacji ich stanu zdrowia. Owa współpraca powinna opierać się na wzajemnym zaufaniu i wsparciu oraz wspólnym określaniu informacji i czynników niezbędnych do powrotu do zdrowia. W interakcji pielęgniarka - pacjent dąży się do stworzenia optymalnych warunków zdrowotnych, które to warunki pacjent jest w stanie samodzielnie podtrzymać w sytuacjach życia codziennego. Tak więc upodmiotowione pielęgniarki przekazują swym pacjentom swoją wiedzę i umiejętności, dają im poczucie zrozumienia i wsparcia, dzięki czemu pacjenci także stają się upodmiotowieni.

Laschinger wraz ze wsp. [24], opracowując model teoretyczny, zaproponowali kilka przykładów praktycznych odnoszących się działań pielęgniarek. Przykłady te odwołują się do wymiarów upodmiotowienia strukturalnego w ujęciu Kanter, tj. dostępu do informacji, dostępu do wsparcia, dostępu do zasobów, dostępu do możliwości uczenia się i rozwoju oraz upodmiotowienia formalnego i nieformalnego. Zgodnie z założeniami opisywanego modelu pielęgniarki, dając swoim pacjentom dostęp do informacji, powinny dostarczać im wszystkich niezbędnych informacji i udzielać wyczerpujących odpowiedzi na zadawane pytania [24]. Ponadto pielęgniarki powinny wykonywać wszelkie czynności dopiero po uprzednim wytłumaczeniu celu i specyfiki swojego działania. Także dozowanie leków oraz poddawanie zabiegom powinny być poprzedzone poinformowaniem pacjenta o istocie i skutkach danego środka lub zabiegu. W upodmiatawiających pacjenta warunkach szpitalnych warto także zadbać, aby pielęgniarki wprowadzały pacjenta w specyfike funkcjonowania szpitala oraz zapoznawały go z nowym otoczeniem szpitalnym.

Dawanie poczucia wsparcia i zrozumienia jest zadaniem trudnym, ale koniecznym z punktu widzenia strategii upodmiotowienia. Okazując wsparcie, pielęgniarki powinny dążyć do poznania uczuć, przekonań i myśli pacjenta, które mogą mieć wpływ na ich dalszą współpracę. Ponadto pacjent powinien czuć, że jego oczekiwania i nadzieje są szanowane, a także że ma prawo wyboru drogi dojścia do zdrowia. Wsparcie wiąże się również z gwarancją, że prawa pacjenta nie zostaną w żadnym wypadku naruszone. Relacja pacjent - pielęgniarka powinna więc opierać się na zasadzie partnerstwa i wzajemnego szacunku [24]. Tworząc atmosferę wsparcia, pielęgniarki poprzez niezwłoczne reagowanie na skargi i zażalenia pacjentów oraz szanowanie wyborów pacjenta mogą dążyć do utrzymania w ich szpitalu klimatu spokoju i zaufania.

Poprzez dostarczanie zasobów gwarantuje się pacjentom ułatwienie im dostępu do zasobów zarówno klinicznych, jak i społecznych. Pacjent powinien mieć możliwość kontaktu ze wszystkimi członkami zespołu interdyscyplinarnego. Powinien mieć także zapewniony czas niezbędny do zrealizowania czynności osobistych (np. higiena osobista, posiłki, odpoczynek). Dostarczanie zasobów to także niesienie pomocy pacjentom w identyfikacji ich osobistych zasobów [39], zdolności samoopieki i własnych mocnych stron [24], a więc także uczenie pacjenta samodzielnego dbania o własne zdrowie. Pielęgniarki powinny dostarczać swoim pacjentom także możliwości uczenia się i rozwoju. Umiejętności te wiążą się głównie z uświadamianiem pacjentom istoty i specyfiki ich własnych problemów zdrowotnych. Jest to możliwe m.in. dzięki zapoznawaniu pacjentów z nowoczesną technologią. Poinformowanego i uświadomionego pacjenta należy jeszcze wesprzeć w stosowaniu nabytej wiedzy i umiejętności w praktyce życia codziennego.

Upodmiotowienie pacjenta nie może pomijać roli rodziny i przyjaciół w procesie optymalizacji zdrowia. Pielęgniarki powinny tworzyć i promować atmosfere silnych sojuszy z pacjentami i wszystkimi członkami zespołu interdyscyplinarnego. Powinny także współpracować z pacjentami i ich rodzinami w celu rozwoju sojuszy wspierających pacjenta w szpitalu i po jego opuszczeniu [24]. Natomiast z punktu widzenia upodmiotowienia formalnego pielęgniarki powinny wspierać i dążyć do rozwoju samodzielności pacjenta. Wszystkie te działania opierają się na zasadach wzajemnej dobrej komunikacji. Pielęgniarki powinny unikać przyjmowania postawy dominującej i narzucania własnego zdania pacjentom. Pacjenci powinni być wręcz namawiani do samodzielnego podejmowania decyzji o własnej opiece zdrowotnej [24].

\section{Upodmiotowienie pacjentów}

Trzeci obszar upodmiotowienia dotyczy pacjentów. Współcześnie zwraca się szczególną uwagę na pacjenta, który jest aktualnym lub potencjalnym świadczeniobiorcą usług medycznych i kształtuje rynek usług medycznych poprzez wyrażanie własnych opinii i oczekiwań. Wymusza to na świadczeniodawcach konieczność dostosowywania się do potrzeb i oczekiwań pacjentów. Koncepcja zabiegania o wysoki standard usług występuje od dawna w założeniach, gorzej natomiast bywa z jej realizacją [40]. Coraz popularniejsza staje się idea dbałości o ofertę zgodną z oczekiwaniami pacjenta i jednocześnie na odpowiednim poziomie profesjonalizmu. Jest to zadanie dosyć trudne w realizacji, gdyż obejmuje swoim zasięgiem całą organizację: kierownictwo i przełożonych, pielęgniarki, a także pacjentów. Konieczne jest monitorowanie jakości usług medycznych nie tylko przez świadczeniodawców, czyli pielęgniarki i ich przełożonych, ale także przez pacjentów. Opinia tych ostatnich ma bowiem duże znacze- 
nie marketingowe, gdyż coraz częściej pacjent, a nie świadczeniodawca, decyduje, w którym zakładzie opieki zdrowotnej będzie się leczył [40].

Placówki opieki zdrowotnej chcące wzmacniać swą pozycję i budować przewagę konkurencyjną w sektorze usług medycznych muszą traktować dobro pacjenta jako wartość podstawową. Wyrazem ich sukcesu będzie właśnie pacjent, który opuszczając placówkę, jest w pełni usatysfakcjonowany ze świadczonych usług i jest przekonany o tym, że gdy zajdzie potrzeba dalszego leczenia lub kolejnej hospitalizacji, usługa znowu będzie wykonana na wysokim poziomie [33]. Współcześnie chory postrzegany jest jako pełnoprawny, czynny współuczestnik procesu pielęgnowania, a realizowane czynności pielęgnacyjne są wynikiem wzajemnej współpracy zespołu medycznego z pacjentem. W dużej jednak mierze to od pielęgniarki zależy, jak pacjent hospitalizowany będzie radził sobie w chorobie, jak zniesie uciążliwości związane z procesem diagnozowania i leczenia, jak zostanie przygotowany do powrotu do środowiska domowego. Zgodnie z koncepcją upodmiotowienia [24] upodmiotowiony pacjent to człowiek, który jest przekonany, że ma dostęp do informacji, wsparcia, zasobów oraz możliwości uczenia się i rozwoju. Owo przekonanie umożliwia optymalizację zdrowia pacjenta, daje poczucie zadowolenia z opieki pielęgniarskiej oraz wzmacnia poczucie kompetencji i możliwości wpływu na własne życie [24]. Wyniki badań wskazują, że satysfakcja z opieki pielęgniarskiej jest najważniejszym wskaźnikiem zadowolenia pacjenta z całościowej opieki świadczonej w szpitalu [33]. Przekonanie pacjenta, że ma większy dostęp do informacji, wparcia, zasobów i możliwości uczenia się, sprawia, że pacjent jest w stanie przenieść nabyte doświadczenia także do sytuacji życia codziennego. Upodmiotowiony pacjent jest więc w stanie dbać o siebie i promować własne zdrowie także po opuszczeniu szpitala. Dodatkowo może także doświadczyć większego poczucia sensu życia oraz większej wiary we własne możliwości i kompetencje [24].

\section{Konkluzje}

Kompleksowa opieka, wzmacnianie pozycji pacjentów i upodmiotowienie ich są przewodnikami w tworzeniu wysokiej jakości opieki, gwarantują pozytywne wyniki zarówno pielęgniarkom, ich przełożonym, jak i ich pacjentom [33]. Model upodmiotowienia zaproponowany przez Laschinger i wsp. [24] opisuje wzajemne relacje zachodzące pomiędzy pielęgniarkami, ich przełożonymi oraz pacjentami oparte na zasadach wynikających ze strategii upodmiotowienia strukturalnego oraz psychologicznego. Wskazuje on także na ważny obszar, jakim jest upodmiotowienie pacjenta. Wzajemna współpraca na tych trzech szczeblach może mieć pozytywny wpływ zarówno na szpital jako organizację, jak i na jego pracowników i oczywiście pacjentów.

Jak to zostało wskazane, strategia upodmiotowienia może być skutecznie stosowana w organizacjach ochrony zdrowia. Choć budowanie otwartości i zaufania nie jest prostym zadaniem, a zaufanie w organizacji jest zależne od wielu czynników [41], to wdrażanie systemowych i konsekwentnych działań, które promują upodmiotowienie, przynosi korzyści organizacji [10]. Podmiotowe zaangażowanie pracowników opieki zdrowotnej, a zwłaszcza pielęgniarek, może przełożyć się na sposób ich podejścia do pacjentów, a w konsekwencji wpływać na postawy samych pacjentów [24]. Opieka pielęgniarska stanowi jeden z ważniejszych i najczęściej ocenianych obszarów działalności zakładu opieki zdrowotnej, a ocena ta uzależniona jest nie tylko od cech osobowościowych reprezentantów personelu pielęgniarskiego, jego merytorycznego przygotowania, poziomu profesjonalizmu, właściwej postawy wobec pacjenta i jego problemów, ale od rozwiązań organizacyjnych leżących w kompetencjach kierownika pionu pielęgniarskiego. Propozycja wdrożenia strategil upodmiotowienia w pracy pielęgniarek może mieć znaczenie dla usprawnienia funkcjonowania instytucji opieki zdrowotnej.

\section{Piśmiennictwo}

1. Kolwitz M. Polski system ochrony zdrowia - perspektywy i możliwości zastosowania systemów opieki zdrowia innych państw Unii Europejskiej. Ann Acad Medicae Stetin. Rocz Pomor Akad Med w Szczecinie. 2010; 56(3): 131-43.

2. Janowski M, Rasińska R. Wybrane zachowania zdrowotne pracowników ochrony zdrowia. Piel Pol. 2015; 2(56): 164-169.

3. Balicki M. Problemy służby zdrowia - diagnoza i recepty. Warszawa: Friedrich-Ebert-Stiftung. Przedstawicielstwo w Polsce wspólnie z Fundacją Międzynarodowe Centrum Badań i Analiz (ICRA); 2013.

4. Wyszkowska Z. Współczesne tendencje w zarządzaniu kadrami w zakładach opieki zdrowotnej. Współ Zarządz. 2013; 2: 90-99.

5. Bugdol M, Bugaj J, Stańczyk I. Procesy zarządzania zasobami ludzkimi w służbie zdrowia. Wrocław: Wydawnictwo Continuo; 2012.

6. WHO. The world health report - health systems fi nancing: The path to universal coverage. Genewa: Światowa Organizacja Zdrowia; 2010.

7. Perek M, Kózka M, Twarduś K. Trudne sytuacje w pracy pielęgniarek pediatrycznych i sposoby radzenia sobie z nimi. Probl Piel. 2007; 15(4): 223-228.

8. Andruszkiewicz A, Banaszkiewicz M, Felsmann M, Marzec A, Kiełbatrowska B, Kocięcka A. Poczucie własnej skuteczności a wybrane zmienne związane z funkcjonowaniem zawodowym w grupie pielęgniarek. Probl Piel. 2011; 19(2): 143-147.

9. Łaguna M, Mielniczuk E, Żaliński A, Wałachowska K. Przywiązanie do organizacji i zaangażowanie w pracę - koncepcje teoretyczne i problemy terminologiczne. Med Pracy. 2015; 66(2): 84-99. 
10. Krawczyk-Bryłka B. Empowerment - strategia zarządzania oparta na zaufaniu. Zarządzanie Finanse. 2012; 4(1): 313330.

11. Moczydłowska JM. Empowerment - upodmiotowienie we wspólnocie. Ekonomika i Organizacja Przedsiębiorstwa. 2013; 11: 15-23.

12. Bombała B. Zagadnienie upełnomocniania pracowników w koncepcji przywództwa personalistycznego i służebnego. Ann Etyka w Życiu Gospod. 2010; 13(1): 123-32.

13. Marzec I. Motywowanie przez upełnomocnienie. Zarządzanie Zasobami Ludzkimi. 2005; 3-4: 41-52.

14. Męczyńska A, Kmieciak R. Czy upełnomocnienie pracowników sprzyja innowacjom w małych i średnich przedsiębiorstwach? Podstawy teoretyczne badań. Zesz Nauk Politechniki Śląskiej. Seria: Organizacja i Zarządzanie. 2011; 57(1847).

15. Teutsch A. Empowerment - Słownik - Równość.info. 2016, http://rownosc.info/dictionary/empowerment/ (data dostępu: 4.04.2016).

16. Deszczyński B. CRM. Strategia. System. Zarządzanie zmianą: Jak uniknąć błędów i odnieść sukces wdrożenia. Warszawa: Wolters Kluwer Polska; 2011.

17. Bugdol M. Wartości organizacyjne. Szkice z teorii organizacji i zarządzania. Kraków: Wydawnictwo Uniwersytetu Jagiellońskiego; 2006.

18. Ahmad N, Oranye O. Empowerment, job satisfaction and organizational commitment: A comparative analysis of nurses working in Malaysia and England. J Nurs Manag. 2010; 18: $582-591$.

19. Saramiento TP, Laschinger H, Iwasiw C. Nurse educator's workplace empowerment, burnout and job satisfaction: Testing Kanter`s theory. J Adv Nurs. 2004; 46(2): 134-143.

20. Rzeźnik B. Empowerment i jego wpływ na zaangażowanie pracowników w przedsiębiorstwie. Prace i Materiały Wydzialu Zarządzania Uniwersytetu Gdańskiego. 2009; 3(2): 343-352.

21. Larkin ME, Cierpial CL, Stack JM, Morrison VJ, Griffith CA. Empowerment Theory in Action: The Wisdom of Collaborative Governance. Online J Issues Nurs. 2008; 13(2): 2-12.

22. Orłowska A, Łaguna M, Celińska-Miszczuk A. Pracownik jako podmiot. Upodmiotowienie w organizacji. (W druku).

23. Dobska M. Empowerment uslugobiorców jako uprawomocnienie dowartościowania się pacjentów. Prace Naukowe Uniwersytetu Ekonomicznego we Wrocławiu. 2014; 355: 129-140.

24. Laschinger H, Gilbert S, Smith LM, Lesile K. Toward's a comprehensove theory of nurse/patient empowerment: applying Kanter's empowerment theory to patient care. J Nurs Manag. 2010; 18: 4-13.

25. Steward JG, McNulty R, Griffin MTQ, Fitzpatrick JJ. Psychological empowerment and structural empowerment among nurse practitiones. J Am Acad Nurse Pract. 2010; 22: $27-34$

26. Wong CA, Laschinger HKS. Authentic leadership, performance, and job satisfaction: The mediating role of empowerment. J Adv Nurs. 2013; 69(4): 947-959.

27. Spreitzer GM. Psychological empowerment in the workplace: Dimensions, measurement and validation. Acad Manage J. 1995; 38(5): 1442-1465.

28. Laschinger HKS, Nosko A, Wilk P, Finegan JE. Effects of unit empowerment and perceived support for professional nursing practice on unit effectiveness and individual nurse well-being: A time-lagged study. Int J Nurs Stud. 2014; 51(12): 1615-1623.

29. Wagner J, Cummings G, Smith DL, Olsen J, Anderson L, Warren $S$. The relationship between structural empowerment and psychological empowerment for nurses: A systematic review. J Nurs Manag. 2010; 18(4): 448-462.

30. Laschinger HKS, Wong CA, Grau AL. Authentic leadership, empowerment and burnout: A comparison in new graduates and experienced nurses. J Nurs Manag. 2013; 21: 541-552.

31. Lautizi M, Laschinger HKS, Ravazzolo S. Workplace empowerment, job satisfaction and job stress among Italian mental health nurses: An exploratory study. J Nurs Manag. 2009; 17(4): 446-452.

32. Orłowska A, Łaguna M. Upodmiotowienie strukturalne a dopasowanie sfery rodzinnej i zawodowej wśród pielęgniarek. Med Pracy. 2016; 6(67): 787-800.

33. Juszczak K, Rykowska I. Rola Naczelnej Pielęgniarki w podnoszeniu jakości usług pielęgniarskich. Piel Pol. 2013; 3: 219-229.

34. Lee M, Koh J. Is empowerment really a new concept? Int J Hum Resour Manag. 2001; 12(4): 684-695.

35. Brajer-Marczak R. Empowerment pracowników w przedsiębiorstwie zorientowanym w zarządzaniu na procesy. Zesz Nauk Wyższej Szkoły Bankowej we Wroclawiu. 2013; 4: 23-35.

36. Gkorezis P, Hatzithomas L, Petridou E. Impact of leader's humor on emploees' psychological empowerment: The moderating role of tenure. J Manag Issues. 2011; 23(1): 83-95.

37. Laschinger HKS, Finegan J, Shamian J, Wilk P. Impact of structural and psychological empowerment on job strain in nursing settings. J Nurs Adm. 2001; 31(5): 260-272.

38. Spreitzer GM. Social structural characteristics of psychological empowerment. Acad Manage J. 1996; 39(2): 483-504.

39. Łaguna M. Zasoby osobiste jako potencjał w realizacji celów. Pol Forum Psychol. 2015; 20(1): 47-61.

40. Małecka B, Marcinkowski J. Satysfakcja pacjenta czynnikiem kształtującym współczesny rynek usług medycznych. Probl Hig Epidemiol. 2007; 88(1): 17-19.

41. Jaklik A, Łaguna M. Zaufanie w organizacji: Analiza sposobów ujęcia i modeli teoretycznych. Psychologia Społ. 2015; 4(35): 369-382.

Artykuł przyjęty do redakcji: 19.12.2016

Artykuł przyjęty do publikacji: 14.06.2017

Źródło finansowania: Praca nie jest finansowana z żadnego źródła. Konflikt interesów: Autorzy deklarują brak konfliktu interesów.

Adres do korespondencji:

Agnieszka Orłowska, Mariola Łaguna

Al. Racławickie 14

20-950 Lublin

e-mail: a_orlowska@onet.pl; laguna@kul.pl

Instytut Psychologii, Wydział Nauk Społecznych

Katolicki Uniwersytet Lubelski Jana Pawła II 